\title{
Effects of the kefir and banana pulp and skin flours on hypercholesterolemic rats ${ }^{1}$
}

\author{
Michel Cardoso de Angelis-PereiraI, Maria de Fátima Píccolo Barcelos ${ }^{\mathrm{II}}$, Mariana Séfora Bezerra Sousa ${ }^{\mathrm{III}}$, Juciane de Abreu \\ Ribeiro Pereira ${ }^{\mathrm{IV}}$ \\ IPhD, Associate Professor, Department of Food Science, UFLA, Lavras-MG, Brazil. Main author. Acquisition and interpretation of data, manuscript \\ writing, critical revision. \\ IIPhD, Associate Professor, Department of Food Science, UFLA, Lavras-MG, Brazil. Conception and design of study, critical revision.

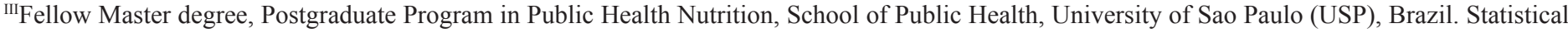 \\ analysis, manuscript writing.

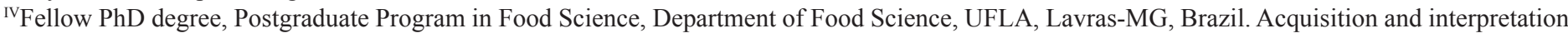 \\ of data, manuscript writing.
}

\begin{abstract}
PURPOSE: To investigate the effect of kefir and banana pulp and skin flours on the serum levels of total cholesterol, HDL-c, LDL-c and triacylglycerols in rats fed cholesterol-rich diet.

METHODS: Thirty Male Wistar rats were used. In the first 21 days, the animals were fed purified hypercholesterolemic diets, except the standard group. In the next 21 days, the animals were given modified diets: Group GC: standard diet AIN-93G; Group HIP: hypercholesterolemic diet; Group F: hypercholesterolemic diet added of 1\% of banana skin flour and 7\% of banana pulp flour; Group Q: hypercholesterolemic diet plus kefir suspension by oral infusion (1.5 ml/animal); Group FQ: hypercholesterolemic diet added of $1 \%$ banana skin flour and $7 \%$ of banana pulp flour plus kefir suspension ( $1.5 \mathrm{ml} /$ animal $)$.

RESULTS: In spite of the high fiber content, the addition of banana pulp (7\%) and skin (1\%) flour did not alter the plasma levels of total cholesterol, HDL-c and LDL-c. However, they reduced the TG levels in $22 \%$. Already fermented kefir reduced significantly the levels of VLDL, LDL-c and triacylglycerols, in addition to having increased HDL-c. However, it was not possible to verify the symbiotic effect between both.
\end{abstract}

CONCLUSION: The results reinforce the beneficial effects of kefir in reducing the risks of cardiovascular diseases.

Key words: Probiotics. Prebiotics. Cholesterol. Cardiovascular Diseases. Rats. 


\section{Introduction}

Cardiovascular diseases (CD) occur as one of the commonest causes of death and are associated with several physiopathological conditions such as arterial hypertension, obesity, excess total cholesterol, low levels of HDL-c and especially high levels of LDL-c. On the other hand, recent investigations in both animals and humans have shown that consumption of some dietary components, as fibers, phytosterols, polyphenols, bioactive peptides and probiotics can modulate the lipid metabolism and so to contribute to reduction of $\mathrm{CD}$.

Probiotics are live microorganisms which, when consumed in an adequate amount, confer benefits on the host health such as improvement of the intestinal function and of the lactose intolerance and reduction of serum lipids ${ }^{1}$. Possible mechanisms to the hypolipidemic effect of probiotics involve: cholesterol assimilation by cells, cholesterol binding to the cell surface, deconjugation of bile salt and non-digestible carbohydrate fermentation producing short chain fatty acids (SCFA) ${ }^{2}$.

Kefir is a probiotic beverage originated from the fermentative activity of kefir grains. These constitute a biological mass with plenty of bacteria and yeasts involved by a matrix of polysaccharides (kefiran), proteins and fats. The mainly microorganisms present in kefir are Lactobacillus paracasei, L. acidophilus, L. kefiri, L. kefiranofaciens, L.kefirgranum, L. parakefir, Candida kefyr and Saccharomyces turicensis. However, its microbiological composition may change due to growing conditions, substrate utilized for proliferation of grains and origin of grains. In addition, the beverage contains a mixture of lactic acid, carbon dioxide, acetaldehyde, ethanol and vitamin B12 $2^{3}$. Its consumption has been associated with the improvement of the immune system, antitumor activity and reduction of cholesterol ${ }^{4,5}$ Although the studies are still scarce and contradictory.

Research also indicates that the consumption combined of probiotics with particular subtracts (prebiotics) can optimize its functional effects. Prebiotics are "a nondigestible food ingredient that beneficially affects the host by selectively stimulating the growth and/or activity of one or a limited number of bacteria in the colon". In that category are included inulin and oligofructose which can be found in onions, artichoke, chicory, garlic, yacon and banana ${ }^{6}$.

Moreover, bananas (Musa ssp) are also known as a source of energy, fibers and resistant starch. Banana pulp flours contain $61-76 \%$ of starch, $6-15 \%$ of total fibers, $2-3 \%$ of soluble fibers and $4-12 \%$ of insoluble fibers ${ }^{7}$. It is important to highlight that in unripe banana pulp flours about $17 \%$ is resistant starch (RS), a kind of starch non-digested/absorbed in the small intestine, but can be fermented in the large intestine and produce beneficial effects as reduced glycemic and of cholesterol ${ }^{8}$. Furthermore, banana consumption has already associated with decreased oxidative stress and increased resistance of LDL-c to oxidation ${ }^{9}$.

Considering the importance of foods to the maintenance of health and the contradictory and scarce results about the benefits of kefir and banana flours, this work goal to evaluate the symbiotic effect of the consumption of kefir and banana pulp and skin flours on the serum lipid profile of rats fed cholesterol-rich diet.

\section{Methods}

The in vivo assay was conducted in Health Sciences College-FACISA/UNIFOR- Formiga-MG-Brazil and was approved by the Research Ethics Committee of the Antonio Carlos President University (UNIPAC), protocol number 001/2004. The chemical analyses were carried out in the Food Science Department of the Federal University of Lavras - UFLA, Lavras-MG-Brazil.

\section{Production of banana skin and pulp flours and obtaining} of kefir suspension

"Prata" banana (Musa paradisiaca) (ripening stage 3) was used for flour-making. The bananas were placed into water at $85^{\circ} \mathrm{C}$ for 10 minutes. Next, the skins were removed by cutting them lengthwise into four parts and dipped into a solution of $0.5 \%$ sodium metabisulfite for 15 minutes to avoid browning. Afterwards, they were submitted to drying in a forced air circulating oven at $60^{\circ} \mathrm{C}$, till the obtaining of constant weight (about 36 hours). The pieces of banana were ground in knife mill and the obtained flour was passed through a 30 mesh sieve $(1.8 \mathrm{~mm})$.

The kefir grain samples were obtained in the Phytopharmaceutical Laboratory of Jose do Rosario Vellano University (UNIFENAS). The kefir grains were cultivated in solution prepared with distilled water and $5 \%$ of brown sugar. The suspension was transferred into bottles and incubated at $25^{\circ} \mathrm{C}$, the change of the nutrient material being done every 24 hours following the methodology proposed by Cardoso et al. ${ }^{10}$.

\section{Chemical composition of banana pulp and skin flours}

The centesimal composition analysis of the flours was conducted according to the methods proposed by the AOAC ${ }^{11}$ and dietary fiber and fractions by utilizing the dietary fiber kit Sigma $^{\circledR}$ following the technique proposed by the $\mathrm{AOAC}^{11}$, which 
are based upon enzymatic gravimetric analyses. The analyses were conducted with five replications for each sort of flour.

In vivo assay

Thirty Male Wistar rats of $70-80 \mathrm{~g}$ body weight were placed in individual cages under controlled conditions of light $(12 \mathrm{~h}$ light $-12 \mathrm{~h}$ dark $)$ and temperature $\left(25^{\circ} \mathrm{C}\right)$ and were given free access to diet and water. After a 7-day acclimation period, the animals were divided randomly into 2 groups: (a) animals fed standard $\operatorname{diet}$ AIN-93G $(\mathrm{n}=6)$ and (b) animals fed hypercholesterolemic diet (cholesterol $0.5 \%$ and hydrogenate vegetable fat 3.5\%) $(n=24)$. After 21 days, these animals were subdivided into five groups:

- Group GC (G1)(n=6): standard $\operatorname{diet}$ AIN-93G;

- Group HIP (G2) (n=6): hypercholesterolemic diet;

- Group F (G3)(n=6): hypercholesterolemic diet added of $1 \%$ of banana skin flour and $7 \%$ of banana pulp flour;

- Group Q (G4)(n=6): hypercholesterolemic diet plus oral infusion of kefir at the dose of $1.5 \mathrm{ml} / \mathrm{animal}(8.6 \mathrm{~g} / \mathrm{kg})$ which corresponds to the dose utilized popularly;

- Group FQ (G5)(n=6): hypercholesterolemic diet added of $1 \%$ of banana skin flour and $7 \%$ of banana pulp flour plus oral infusion of kefir suspension at the dose of $1.5 \mathrm{ml} / \mathrm{animal}$ $(8.6 \mathrm{~g} / \mathrm{kg})$.

The intervention with kefir and the banana flours lasted 21 days. The total duration of the experiment was of 42 days.

The diets were made according to Reeves et al. ${ }^{12}$ of the American Institute of Nutrition (AIN), amounting to five different diets with some modifications in relation to the lipid and carbohydrate source and concentration (Table 1) following the AIN$93 \mathrm{G}$ pattern (for growth). The addition of $3.5 \%$ of hydrogenated vegetable fat into the cholesterol- raising diets occurred to the detriment of $3.5 \%$ of soybean oil among the $7 \%$ recommended by the AIN-93G. The diets of the groups which were given the banana flours underwent detriment of the carbohydrate source.
TABLE 1 - Composition of the five diets characterized by the different treatments fed to the experimental animals.

\begin{tabular}{|c|c|c|c|c|c|}
\hline \multirow{3}{*}{ Ingredients } & \multicolumn{5}{|c|}{ Groups } \\
\hline & GC & HIP & $\mathbf{F}$ & $\mathbf{Q}$ & FQ \\
\hline & \multicolumn{5}{|c|}{ (g/kg) } \\
\hline Cornstarch & 397.486 & 396.486 & 396.486 & 396.486 & 396.486 \\
\hline Casein & 200.000 & 200.000 & 200.000 & 200.000 & 200.000 \\
\hline Dextrin & 132.000 & 132.000 & 58.000 & 132.000 & 58.000 \\
\hline Sucrose & 100.000 & 100.000 & 100.000 & 100.000 & 100.000 \\
\hline Soybean oil & 70.000 & 35.000 & 35.000 & 35.000 & 35.000 \\
\hline G.V.H. & - & 35.000 & 35.000 & 35.000 & 35.000 \\
\hline Cellulose & 50.000 & 50.000 & 50.000 & 50.000 & 50.000 \\
\hline Pre-mix min AIN-93 G & 35.000 & 35.000 & 35.000 & 35.000 & 35.000 \\
\hline Pre-mix vita AIN-93 & 10.000 & 10.000 & 10.000 & 10.000 & 10.000 \\
\hline L-Cystine & 3.000 & 3.000 & 3.000 & 3.000 & 3.000 \\
\hline Choline bitartarate & 2.500 & 2.500 & 2.500 & 2.500 & 2.500 \\
\hline $\begin{array}{l}\text { Cholesterol }+ \text { folic acid } \\
(7: 3)\end{array}$ & - & 1.000 & 1.000 & 1.000 & 1.000 \\
\hline TBHQ & 0.014 & 0.014 & 0.014 & 0.014 & 0.014 \\
\hline $\begin{array}{l}\text { Banana flour (pulp and } \\
\text { skin) }\end{array}$ & - & - & 80.00 & - & 80.00 \\
\hline
\end{tabular}

Euthanasia of the animals and sample collection

At the end of the experiment, all rats were fasted for $12 \mathrm{~h}$ prior to sacrificial. Animals were anesthetized with ethylic ether by inhalation. The blood was drawn from the great vessels by means of the thoracic and abdominal openings. The samples were centrifuged at 3000rpm for five minutes in an Eppendorf/ Centrifuge $5415^{\circledR}$ centrifuge for obtaining serum.

The analyses of the lipid fractions were undertaken by the colorimetric -enzymatic method by means of the commercial kit of the In Vitro Diagnostica ${ }^{\circledR}$ mark code CAT.: 10552 for total cholesterol (CT), CAT.: 10724 for triacylglycerol (TG) and CAT.: 044 for high density lipoprotein (HDL-c).

Total cholesterol was determined after enzymatic hydrolysis and oxidation of the serum samples. The indicator quinoneimine is formed from hydrogen peroxide and 4aminofenazona in the presence of phenol and peroxidase. Triacylglycerols were determined after enzymatic hydrolysis with lipases. The indicator is quinoneimine formed from hydrogen peroxide, 4-aminoantipirina and 4- chlorophenol under the catalytic influence of peroxidase. Reading in a spectrophotometer at $500 \mathrm{~nm}$ was conducted for both determinations.

The fraction HDL-c was determined by precipitation 
of chylomicrons, VLDL (very low density lipoprotein) and LDL-c (low density lipoprotein) with phosphotungstic acid and magnesium chloride. After centrifugation at $4000 \mathrm{rpm}$ for 10 minutes, the fraction HDL-c remains on the supernatant, its being determined by utilizing the kit and methodology by the enzymatic method previously reported for total cholesterol.

The fraction LDL-c + VLDL cholesterol was determined by difference between the total cholesterol total and the content of HDL-c according to the formula by Friedwald ${ }^{13}$.

\section{Statistical analysis}

The results are expressed as mean \pm standard deviation. For comparison of the arithmetic means Tukey test are employed using the software GraphPad InStat. The significance level of 5\% $(\mathrm{p}<0.05)$ was adopted.

\section{Results}

Banana pulp and skin flours composition (Musa paradisiaca)

The chemical composition of the banana pulp and skin flours (Musa paradisiaca) is in Table 2.

TABLE 2 - Average values (\%) and standard deviation of the composition of banana pulp and skin flours (wet basis).

\begin{tabular}{ccc}
\hline Parameters & $\begin{array}{c}\text { Banana } \\
\text { pulp flour }\end{array}$ & $\begin{array}{c}\text { Banana } \\
\text { skin flour }\end{array}$ \\
\hline Moisture & $9.92 \pm 0.44$ & $5.07 \pm 0.24$ \\
Ashes & $2.32 \pm 0.23$ & $11.09 \pm 0.18$ \\
Protein & $4.76 \pm 0.14$ & $8.12 \pm 0.02$ \\
Lipids & $0.38 \pm 0.03$ & $10.67 \pm 0.19$ \\
Digestible carbohydrates & $67.80 \pm 1.10$ & $25.11 \pm 2.34$ \\
Soluble dietary fiber & $3.83 \pm 0.48$ & $3.53 \pm 0.47$ \\
Unsoluble dietary fiber & $10.99 \pm 0.46$ & $36.41 \pm 2.04$ \\
\hline
\end{tabular}

Influence of kefir consumption and banana flours in the plasma levels of lipids

The Table 3 shows the average contents of total cholesterol, HDL-c, non-HDL cholesterol (VLDL + LDL-c) and triacyglycerols of Wistar rats fed cholesterol-rich diets, either with or without the addition of kefir and banana pulp and skin flour.
TABLE 3 - Average values (mg.dL- ${ }^{1}$ ) of total cholesterol (CT), HDL-c, non-HDL fraction (VLDL-c + LDL-c) and triacyglycerols (TG) in hypercholesterolemic Wistar rats.

\begin{tabular}{ccccc}
\hline & \multicolumn{4}{c}{ Parameters } \\
\cline { 2 - 5 } Groups & CT & HDL-c & VLDL-c + LDL-c & TG \\
\hline GC & $73.00 \pm 9.76^{\mathrm{b}}$ & $44.00 \pm 5.07^{\mathrm{d}}$ & $31.13 \pm 8.33^{\mathrm{ab}}$ & $90.00 \pm 15.22^{\mathrm{ab}}$ \\
HIP & $93.20 \pm 11.54^{\mathrm{a}}$ & $54.37 \pm 4.74^{\mathrm{bc}}$ & $41.73 \pm 10.20^{\mathrm{a}}$ & $108.92 \pm 8.53^{\mathrm{a}}$ \\
F & $85.75 \pm 8.94^{\mathrm{ab}}$ & $50.03 \pm 4.75^{\mathrm{cd}}$ & $33.80 \pm 5.31^{\mathrm{ab}}$ & $84.37 \pm 17.26^{\mathrm{b}}$ \\
Q & $83.42 \pm 7.86^{\mathrm{ab}}$ & $64.95 \pm 4.23^{\mathrm{a}}$ & $20.25 \pm 4.29^{\mathrm{b}}$ & $67.15 \pm 6.39^{\mathrm{c}}$ \\
FQ & $84.47 \pm 5.77^{\mathrm{ab}}$ & $59.60 \pm 5.89^{\mathrm{ab}}$ & $26.35 \pm 2.74^{\mathrm{b}}$ & $77.30 \pm 6.39^{\mathrm{b}}$ \\
\hline
\end{tabular}

$\mathrm{GC}=$ standard diet; AIN-93G; HIP=hypercholesterolemic $\operatorname{diet} ; \mathrm{F}=$ hypercholesterolemic diet added of $1 \%$ of banana skin flour and 7\% of banana pulp flour; $\mathrm{Q}=$ hypercholesterolemic diet plus kefir; $\mathrm{FQ}=$ hypercholesterolemic diet added of $1 \%$ of banana skin flour and $7 \%$ of banana pulp flour plus application of kefir suspension.

\section{Discussion}

Banana pulp and skin flours composition (Musa paradisiaca)

It was observed that $100 \mathrm{~g}$ of banana pulp flour contains $14.82 \%$ dietary fiber while skin flour has $39.94 \%$ of fibers. JuarezGarcia et $a l .{ }^{8}$ also found $14.5 \%$ of fibers for Musa paradisiaca pulp flour. Considering the recommendation of the Brazilian Society of Cardiology ${ }^{14}$ which advises the consumption of $20-30 \mathrm{~g} /$ fiber/day, these flours are potential sources of fibers contributing significantly towards the recommended daily intake.

It is important to emphasize that from the total fiber content of banana pulp and skin flours, $10.99 \%$ and $36.41 \%$ are insoluble fibers, respectively. These include cellulose, hemicellulose and lignin which increase satiety and improve intestinal transit. In addition, about $3 \%$ are soluble fibers (gums and pectin), standing for about $42 \%$ of the daily requirements. Soluble fibers play an important role in the control of cholesterol absorption and therefore are indicated as one of the therapeutic elements in dyslipidemias ${ }^{14}$. These values agree with those of Mota et al. ${ }^{7}$ who found $3.05 \%$ of soluble fibers in 'Prata' banana flour.

Also, banana skin flour contains high concentrations of ashes, lipids and proteins. However, pulp flour presented only $3.32 \%$ of ashes, $4.76 \%$ of proteins and $0.38 \%$ of lipids. In a similar way, Borges et al. ${ }^{15}$ found $2.59 \%$ of ashes, $4.5 \%$ of proteins and $0.68 \%$ of lipids in unripe banana flour (Musa spp.) cultivar 'Prata'. 
Influence of kefir consumption and banana flours in the plasma levels of lipids

The animals fed only cholesterol-rich diet presented statistical increase in the levels of total cholesterol relative to the control group, indicating that this model is capable of inducing hyperlipidemias. Nevertheless, the concentration of cholesterol used in these diets was not capable of inducing hypertriglyceridemia. Similarly, Liu et al. ${ }^{16}$ did not find any increase of triacylglycerols in hamsters fed $0.35 \%$ of cholesterol for eight weeks.

In spite of the high fiber content, the addition of banana pulp (7\%) and skin (1\%) flour did not alter the plasma levels of total cholesterol, HDL-c and LDL-c. However, they reduced the TG levels in $22 \%$. In this group, the TG contents were similar to the standard group (without the addition of cholesterol). Horigome et al. ${ }^{17}$ found that the banana pulp (Musa sapienturn L., cv. Cavendishii), unripe or ripe, dehydrated $\left(-30^{\circ} \mathrm{C}\right)$ was capable of reducing the serum levels of total cholesterol and LDL-c. But, banana pulp flour dried at $65^{\circ} \mathrm{C}$ did not result into the same effect. The authors claim that the fraction fiber was likely altered during the heating by browning reactions, resulting into the disappearance of the hypocholesterolemic effect of the banana pulp.

On the other hand, bananas are also sources of flavonoids, chemical compounds which possess the capacity of modulating lipid metabolism. In this context, Vijayakumar et al. ${ }^{18}$ investigated the effect of single flavonoids of unripe banana (Musa paradisiaca L.) $(1 \mathrm{mg} / 100 \mathrm{~g}$ of weight) on mice metabolic control. It was found that after 45 intervention days, flavonoids reduced total cholesterol by increase in the degradation and elimination of cholesterol via bile acids and neutral sterols. Besides, they decreased the levels of serum triacylglycerols by increase of the activity of lipase lipoprotein in the adipose tissue. Flavonoids also decreased the activity of enzymes glucose-6-phosphate dehydrogenase and malate dehydrogenase.

Yin et al. ${ }^{9}$ evaluated the effect of the consumption of a single meal of banana $(400 \mathrm{~g})$ on serum lipids and oxidative stress of 20 healthy volunteers. In this study, there was significant reduction in the plasma levels of lipid peroxides (26.6\%) and increase in the resistance of LDL-c to oxidation, but there was not alteration in serum total cholesterol levels.

Already fermented kefir reduced significantly the levels of VLDL, LDL-c and triacylglycerols, in addition to having increased HDL-c. The fall in serum lipids was similar to that found by Liu et al. ${ }^{4}$ who showed that the consumption of milk and soybean kefir fermented for eight weeks decrease non-HDL cholesterol, TG and the accumulation of cholesterol in the liver in hamsters fed cholesterol rich diet. In another study, the addition of kefir into the water consumed by broiler chickens $(5 \%$ and $7.5 \%$ ) caused reduction in serum total lipids and CT in a dosedependent way ${ }^{5}$. Wang et al. ${ }^{19}$ also found decrease of CT and TG by Lactobacillus plantarum MA2 ( $10^{11}$ cells/day) isolated from Tibet kefir. Contrarily, in the study of St-Onge et al. ${ }^{20}$ the consumption of kefir ( $500 \mathrm{~mL} /$ day / 4 weeks) by hyperlipidemic men was not able to affecting CT, LDL-c, HDL-c and TG. In this case, both the type and amount of bacteria contained in the kefir as well as the intervention time may not be adequate to alter the cholesterol metabolism.

The hypolipidemic mechanisms of kefir are not fully understood. Some studies show that both bacteria and yeasts present in kefir produce bile salt hydrolases (BSH), enzymes which deconjugate bile salts. These when deconjugated are excreted by feces ${ }^{16}$. Regards to that, seem to have increased co-precipitation of cholesterol with bile acids decreasing their absorption. Kefir can also act in the reduction of cholesterol synthesis by means of short-chain fatty acids and by inhibiting the activity of enzyme HMG-CoA reductase ${ }^{5}$. However, further studies are necessary to prove the effects of kefir on the lipid metabolism and elucidate its possible mechanisms of action.

Bananas are considered sources of inulin, an important prebiotic which associated with lactic bacteria can optimize the benefits of probiotics. Thus, supplying kefir together with banana flours was opted for. However, it was not possible to verify the symbiotic effect between both.

\section{Conclusions}

At the concentrations utilized, the banana pulp and skin flours did not influence the plasma lipid levels of the animals fed cholesterol-rich diet. However, the fermented kefir significantly reduced the plasma levels of the VLDL and LDL-c and triacylglycerols as well as raised the levels of HDL-c, which reinforces its beneficial effects in reducing the risks of cardiovascular diseases.

\section{References}

1. FAO. Food and Agriculture Organization of the United Nations/ World Health Organization. Guidelines for the evaluation of probiotics in food: report of a Joint FAO/WHO Working Group on Drafting Guidelines for the Evaluation of Probiotics in Food, London, Ontario, Canada. 2002. Available from http://www.who. int/foodsafety/publications/fs_management/probiotics2/en/index. html

2. Kumar M, Nagpal R, Kumar R, Hemalatha R, Verma V, Kumar A, 
Chakraborty C, Singh B, Marotta F, Jain S, Yadav H. Cholesterollowering probiotics as potential biotherapeutics for metabolic diseases. Exp Diabetes Res. 2012;2012:1-14.

3. Guzel-Seydim Z, Kok-Tas T, Greene AK, Seydim AC. Review: functional properties of kefir. Crit Rev Food Sci Nutr. 2011;51(3):261-8

4. Liu J, Wang S, Chen M, Chen H, Yueh P, Lin C. Hypocholesterolaemic effects of milkkefir and soyamilkkefir in cholesterolfed hamsters. $\mathrm{Br}$ J Nutr. 2006;95(5):939-46.

5. Cenesiz S, Yaman H, Ozcan A, Kart A, Karademir G. Effects of kefir as a probiotic on serum cholesterol, total lipid, aspartate amino transferase and alanine amino transferase activities in broiler chicks. Medycyna Weterynaryjna. 2008;64(2):168-70.

6. Gibson GR, Roberfroid MB. Dietary modulation of the colonic microbiota: introducing the concept of prebiotics. J Nutr. 1995; 125:1401-12.

7. Mota RV, Lajolo FM, Ciacco C, Cordenunsi BR. Composition and functional properties of banana flour from different varieties. Starch. 2000;52(2):63-8.

8. Garcia EJ, Acevedo EA, Ayerdi SGS, Ambriz SLR, Pérez LAB. Composition, digestibility and application in bread making of banana flour. Plant Foods Hum Nutr. 2006;61(3):131-7.

9. Yin X, Quan J, Kanazawa T. Banana prevents plasma oxidative stress in healthy individuals. Plant Foods Hum Nutr. 2008;63:71-6.

10. Cardoso LGV, Ferreira MS, Schneedorf JM, Carvalho JCT. Avaliação de fermentado de quefir sobre o trânsito intestinal de ratos. J Bras Fitomed. 2003;1(3):107-9.

11. AOAC. Association of Official Analytical Chemists. Official methods of analysis. 17th ed. Gaithersburg: Md/AOAC; 2005.

12. Reeves PG, Nielsen FH, Faheey GC. AIN-93 Purified diets for laboratory rodents: final report of the American Institute of Nutrition ad Hoc Writing Committee on the reformulation of the AIN-76A rodent diet. J Nutr. 1993;123(11):1939-51.

13. Friedwald WT, Levy RI, Fredrickson DS. Estimation of the concentration of low density lipoprotein cholesterol in plasma, without use of preparative ultracentrifuge. Clin Chem. 1972;18:499502.

14. Sposito AC, Caramelli B, Fonseca FAH, Bertolami MC. IV Diretriz Brasileira sobre Dislipidemias e Prevenção da Aterosclerose: Departamento de Aterosclerose da Sociedade Brasileira de Cardiologia. Arq Bras Cardiol. 2007;28(Supl 1):2-19.

15. Borges AM, Pereira J, Lucena EMP. Caracterização da farinha de banana verde. Ciênc Tecnol Aliment. 2009;29(2):333-9.

16. Liu H, Xie Y, Xiong L, Dong R, Pan C, Teng G, Zhang H. Effect and mechanism of cholesterol-lowering by kluyveromyces from tibetan kefir. Adv Mat Res. 2012,343:1290-8.

17. Horigome T, Sakaguchi E, Kishimoto C. Hypocholesterolaemic effect of banana (Musa sapientum L. var. Cavendishii) pulp in the rat fed on a cholesterol-containing diet. Br J Nutr. 1992;68(1):23144.

18. Vijayakumar S, Presannakumar G, Vijayalakshmi NR. Investigations on the effect of flavonoids from banana, Musa Paradisiaca L. on lipid metabolism in rats. J Diet Suppl. 2009;6(2):111-23.

19. Wang Y, Xu N, Xi A, Ahmed Z, Zhang B, Bai X. Effects of Lactobacillus plantarum MA2 isolated from Tibet kefir on lipid metabolism and intestinal microflora of rats fed on high-cholesterol diet. Appl Microbiol Biotechnol. 2009;84:341-7.

20. St-Onge MP, Farnworth ER, Savard T, Chabot D, Mafu A, Jones PJH Kefir consumption does not alter plasma lipid level or cholesterol fractional syntheses rates relative to milk in hyperlipidemic men. BMC Complement Altern Med. 2002;2(1):1-7

\section{Correspondence:}

Michel Cardoso de Angelis-Pereira

Departamento de Ciência dos Alimentos

Campus UFLA-DCA

37200-000 Lavras - MG Brasil

Tel.: (55 35)3829-1406 Ramal: 1992

deangelis@dca.ufla.br

Received: March 14, 2013

Review: May 16, 2013

Accepted: June 13, 2013

Conflict of interest: none

Financial sources: National Council for Technological and Scientific Development (CNPq), National Foundation for Development of Private Higher Education (FUNADESP) and University Center Formiga (UNIFOR)

${ }^{1}$ Research performed at Laboratory Analysis of Food, Food Science Department, Federal University of Lavras (UFLA) and Health Sciences College, University Center Formiga (UNIFOR), Minas Gerais, Brazil. 